\title{
LEISURE AND WORK IN CONTEMPORARY URBAN-METROPOLITAN SPACE
}

\author{
lazer e trabalho no espaço urbano-metropolitano contemporâneo
}

\author{
Angelo Serpa *
}

\begin{abstract}
Resumo
O ponto de partida para a discussão proposta neste artigo é a premissa de que a produção dos espaços de lazer está indissociável e dialeticamente relacionada com a produção dos espaços de trabalho nas cidades e metrópoles da contemporaneidade. Parte-se também do pressuposto de que as relações capital-trabalho/ trabalho-lazer experimentaram modificações relevantes nas últimas décadas, que devem ser consideradas na análise da temática proposta. Busca-se caracterizar as transformações econômicas, políticas, sociais e culturais das relações capital-trabalho/trabalho-lazer no mundo contemporâneo, a partir da consolidação da sociedade industrial e da era moderna, para, em seguida, apresentar um estudo de caso específico em bairros populares de Salvador e Feira de Santana, sobre o trabalho e o lazer de microempreendedores, microempresários e consumidores dos bairros analisados, indicando e problematizando essas transformações em um contexto espaço-temporal específico. Por fim,com base nos conceitos de "ócio criativo" e "teletrabalho", amplia-se a discussão para refletir como as mudanças nas relações capital-trabalho/trabalho-lazer podem impactar o dia a dia das cidades e metrópoles, aprofundando uma visão prospectiva sobre esses impactos em contexto urbano e metropolitano.
\end{abstract}

Palavras-chave: Lazer; Trabalho; Empreendedorismo; Ócio Criativo; Cidade; Metrópole.

\begin{abstract}
The starting point for the discussion proposed in this article is the premise that the production of leisure spaces is inseparable and dialectically related to the production of work spaces in contemporary cities and metropolises. It is also based on the assumption that capital-work/work-leisure relationships have undergone relevant modifications in recent decades, which should be considered in the analysis of the proposed theme. The aim is to characterize the economic, political, social and cultural transformations of capital-work/work-leisure relationships in the contemporary world, starting from the consolidation of industrial society and the modern era, and moving on to present a specific case study of working class neighborhoodsin Salvador and Feira de Santana, about the work and leisure of micro-entrepreneurs, the proprietors of micro-businesses, and consumers in neighborhoods in the study, indicating and problematizing these transformations in a spatial-temporal context. Finally, based on the concepts of "creative idleness" and "telework" the discussion is widened to reflect on how the changes in capital-work/work-leisure relationships may impact on daily life in cities and metropolises, deepening a prospective vision of these impacts in an urban and metropolitan context.
\end{abstract}

Key words: Leisure, Work, Entrepreneurship, Creative Idleness, City, Metropolis.

\section{Resumen}

Para la discusión propuesta en este artículo, se toma como punto de partida, la premisa de que la producción de los espacios de ocio es indisociable y dialécticamente relacionada con la producción de los espacios de trabajo en las ciudades y metrópolis contemporáneas. Se parte también del supuesto de que las relaciones capital-trabajo/trabajo-ocio experimentaron modificaciones relevantes en las últimas décadas, que deben ser consideradas en el análisis de la temática propuesta. Se busca caracterizar las transformaciones económicas, políticas, sociales y culturales de las relaciones capital-trabajo/trabajo-ocio en el mundo contemporáneo, a partir de la consolidación de la sociedad industrial y de la era moderna, para, después, presentar un estudio de caso específico en barrios populares de Salvador y Feira de Santana, sobre el trabajo y el ocio de microemprendedores, microempresarios y consumidores de los barrios analizados, evidenciando y problematizando esas transformaciones en un contexto espacio temporal específico. Por último, con base en los conceptos de "Ocio creativo" y "teletrabajo", se amplía la discusión para reflexionar en cómo las mudanzas en las relaciones capital-trabajo/trabajo-ocio pueden impactar el día a día de las ciudades y metrópolis, profundizando en una visión prospectiva sobre tales impactos en un contexto urbano y metropolitano.

Palabras clave: Ocio; Trabajo; Iniciativa empresarial; Ocio creativo; Ciudad; Metrópolis

(*) Lecturer, Doctor of the Federal University of Bahia (Universidade Federal da Bahia) - Rua Barão de Geremoabo, s/n, CEP:40170-290, Salvador (BA), Brasil. Tel: (+55 71) 32838569 - angeloserpa@hotmail.com 


\section{INTRODUCTION}

To speak of leisure spaces in the production of metropolises means discussing the socio-spatial relationships encompassed by the phenomenon, linking it to its dialectic and inseparable pair: work spaces in the contemporary metropolitan context. In other words, problematizing leisure also implies thinking about work, especially the multiples of space-time involved in both activities. While recognizing and taking the risk that this reflection may be out of tune with the interventions of my fellow colleagues on this round table, I begin with the assumption that capital-work/work-leisure relationships have been subjected to important modifications in recent decades that need to be considered in the analysis of the proposed theme.

Based on the thinking of David Harvey, Hannah Arendt and Richard Sennett the initial intention is to characterize the economic, political, social and cultural transformations of capital-work/ work-leisure in the contemporary world, starting from the consolidation of industrial society and the modern era, and subsequently to present a specific case study in working-class neighborhoods in Salvador and Feira de Santana about the work and leisure of microentrepreneurs, proprietors of micro-businesses and consumers in these locations, showing and problematizing these transformations in a specific spacial-temporal context. Thirdly, based mainly on the concepts of "creative idleness" and "telework", as conceived by Domenico de Masi, the discussion is amplified to reflect on how changes in capital-work/work-leisure relationships can impact on daily life in cities and metropolises, deepening the prospective vision of these impacts in urban and metropolitan contexts.

As an introduction I will begin with the issue of work and automation. Labor and capital are inseparable in the capitalist mode of production, but the work of social reproduction was not (or was marginally) incorporated as productive work in the dialectic of the means of production. That is, housekeeping and caring for children or one selfare not considered productive work. This is the logic of the means of production, and even with what we call the flexible accumulation of capitalism in its current phase, this maxim still holds.

If the logic of productive work in core countries, and later in peripheral countries, tends towards automation and flexibility, increased precariousness and the short term, then reproductive work in the ambit of the private sphere, of the family and the individual, is long term. So, what would the world be like with less productive work (freed by automation) and more time for labor, for reproductive work?

It is clear that there are also consequences for the dialectic of leisure and work in the form that it is known today. Leisure is reproduction, work is production, but what would leisure and work be like when dialectically related in the sphere of reproduction? For example, in "The Fall of Public Man" (SENNETT, 1998), Richard Sennett shows how children's games prepare future adult for social rules, to control their emotions and self-distancing, and to negotiate their emotions in the public sphere. That is, playfulness is a precondition for cooperation between human beings, for social existence. The contradiction is that nowadays playfulness has been captured by the logic of the mode of production; leisure has become the possibility of making a profit, although in the urban-metropolitan cracks and crevices the playful and art can help subvert relationships from their current established forms (SERPA, 2007).

\section{ON CAPITAL-WORK/WORK-LEISURE RELATIONSHIPS IN THE CONTEMPORARY WORLD}

In a lecture given at the XIII SIMPURB, in Rio de Janeiro, David Harvey stated that when capital is doing very well, in general, people are doing very badly, emphasizing that this fissure between capital's wellbeing and people's wellbeing grows continually faster in both quantitative and qualitative terms. Referring to Marx's concept of alienation, Harvey asks himself "what the relationship is between the professional life and quality of life" and "how far will people go without saying that they cannot live this way" (HARVEY, 2014, p. 55). 
Harvey refers to a survey on professional satisfaction in the United States that revealed that $70 \%$ of the population "have an aversion to or are absolutely indifferent to the work they carry out", believing "that they live in workplaces with totally unimportant jobs, that they do not take pride in, which are unsatisfying and that they consider tedious" (HARVEY, 2014, p. 55). In this context, the author raises a particularly pertinent question for the discussion proposed herein: "Why, in a society that has created every type of timesaving technology do most of us, in fact, have less time to think and relax?" (op. cit.).

\section{WORK AND LEISURE IN THE MODERN ERA: INDUSTRIAL SOCIETY}

According to several authors, the functional (and radical) separation between work and leisure - in both temporal and spatial terms - goes back to the dawn of industrial society. Evidently this had consequences for the city, which

in turn, also specializes itself: developing industrial zones, where production takes place; residential neighborhoods, to rest in; commercial neighborhoods, to shop in; zones for leisure, places for fun, etc. This is the functional city, so dear to Corbusier (...) a synchronized factory requires a synchronized city (...) the city is congested neighborhood after neighborhood, due to the displacement of all its inhabitants at the same time; this is one of the greatest wastes of industrial society (DE MASI, 2000, p. 57).

Hannah Arendt states that the danger of automation in industrial society is "less the much deplored mechanization and artificialization of natural life", but the unprecedented intensification of society's vital process of reproduction; as the rhythm of the machines increase "the natural rhythms of life enormously", undermining the durability of the human world (ARENDT, 2000, p. 144-145). Her reasoning is based on the distinction between labor and work. The former is concentrated "exclusively on life and its maintenance, is so oblivious of the world that it might as well not exist", whose products - the result of the metabolism of humans with nature - "do not stay in the world long enough to become a part of it" (op. cit., p. 130), whilst the latter "fabricates the endless variety of things whose sum total constitutes human artifice. They are mostly, but not exclusively, durable objects for use" (op. cit., p. 149) and "the things of the world have the function of stabilizing human life" (p. 150).

Arendt criticizes Marx for not making this distinction between labor and work, between animal laborans and homo faber, a criticism that she extends to other social thinkers of the so-called "modern era". However, for her, the distinction between productive and unproductive (or reproductive) work has, even today, "albeit in a prejudicial manner", "the most fundamental distinction between work and labor":

The modern age in general and Karl Marx in particular, overwhelmed, as it were, by the unprecedented actual productivity of Western mankind, had an almost irresistible tendency to look upon all labor as work and to speak of the animal laborans in terms much more fitting for homo faber, hoping all the time that only one more step was needed to eliminate labor and necessity altogether. No doubt the actual historical development that brought labor out of hiding and into the public realm, where it could be organized and "divided," constituted a powerful argument in the development of these theories. (...) Unlike the productivity of work, which adds new objects to the human artifice, the productivity of labor power produces objects only incidentally and is primarily concerned with the means of its own reproduction (...) never "produces" anything but "life" (ARENDT, 2000, p. 98-99).

From this perspective, labor and consumption are only "two stages of the same process, imposed upon man by the necessities of life", leveling "all human activities to the common denominator of securing the necessities of life and providing for their abundance" (ARENDT, 2000, p. 139). Following arendtian reasoning we reach the classical opposition between work and leisure, typical of the modern era and industrial society: 
The (...) trend to reduce all serious activities to the status of making a living is manifest in present-day labor theories, which almost unanimously define labor as the opposite of play. As a result, all serious activities, irrespective of their fruits, are called labor, and every activity which is not necessary either for the life of the individual or for the vital process of society is classified as leisure (...) From the standpoint of "making a living" any activity unconnected with labor becomes a "hobby". (ARENDT, 2000, p. 139-140).

In other words, the work equated with labor corresponds to need, and leisure to liberty, as "it is indeed remarkable to see how plausible it is for modern thinking to consider leisure to be a source of freedom." (ARENDT, 2000, p.139). Arendt finds the role of the hobby in modern society surprising and hypothesizes that this is at the root of experience in work-leisure theories: in Marx's utopian society, free from work, "all activities would be performed in a way which very closely resembles the manner of hobby activities" (op. cit., p. 140). However, Marx's utopia, where free time would emancipate men from need, making animal laborans productive is fallacious as this free time "is never spent on anything but consumption, and the more time left to him, the greedier and more craving his appetites" (op. cit., p. 146).

The fact that these appetites become more sophisticated, so that consumption is no longer restricted to necessities but, on the contrary, concentrates mainly on the superfluities of life, does not change the character of this society, but harbors the grave danger that eventually no object in the world will be safe from consumption and annihilation through consumption. (ARENDT, 2000, p. 146).

\section{RECENT CHANGES TO THE WORLD OF WORK}

For Sennett (2006), automation has had deep influences on the bureaucratic pyramid of public and private institutions, especially in core countries, drastically reducing its base from the end of the twentieth century. Thus, in both manual and intellectual work, thanks to innovative technologies, organizations can disseminate routine tasks more efficiently: "It is not just that it has become possible to simply reduce the size of the workforce, in addition management can reduce the functional layers of the base - an institutional army in which the soldiers are circuits" (SENNETT, 2006, p. 46). This especially hinders the inclusion of the masses in the workplace, leaving out "the most vulnerable elements of society, those who want to work but do not have specialized skills" (op. cit.).

Sennett defends the idea that at the end of the twentieth century the capitalist mode of production turned some decisive pages: power shifted from management to the shareholders of large companies, investment banking services effectively became international; investors took on the active position of judges, building up or breaking up entire companies; a focus on short-term rather than long-term results; the "delayering of institutions", with the delegation of certain functions to third parties in other businesses; attracting or disposing of employees as the company moves from one task to another; shortening the organization's operational time with an increased focus on immediate and smaller tasks (SENNETT, 2006, p. 41-51). Sennett also points to how as a consequence of these institutional transformations, there are three main losses for companies: "a low level of institutional loyalty, a reduction of the informal confidence among workers and a weakening of institutional knowledge" (op. cit., p. 62).

The result of these processes is the crumbling of work identities in a context of constantly reinvented institutions: "Most corporate restructuring processes have (...) the character of a self-consuming passion in action, especially in the quest for prospective synergies in the processes of company mergers" (SENNETT, 2006, p. 131). This is the same self-consuming passion that causes the consumer to look for the stimulus of difference in increasingly homogenous products, like a "tourist travelling from one cloned city to another, visiting the same shops, where they buy the same products. However, the point is that they have travelled: for the consumer the stimulus is 
in the process of movement itself" (op. cit., p. 137). This is also how workers, objects and places become disposable, as the constant search for new stimuli means renunciation and disposal no longer experienced as loss.

In the working world of the new capitalism, lifetime employment has gradually disappeared, along with careers dedicated to a single institution. Temporary work has increased and is the fastest growing sector of the workforce in countries such as the United States and Great Britain, currently accounting for

$8 \%$ of the American workforce. If we add people employed on short-term contracts to avoid expenses with benefits, in the retail trade, restaurants and other jobs in the service sector, the percentage would be around one fifth of the workforce. (SENNETT, 2006, p. 51).

Sennett takes the view, particularly interesting for the discussion proposed herein, that these transformations alter the character of the individuals submitted to them, asking how long-term objectives can be sought in a short-term society, how narratives of identity and life history can be developed in a society composed of episodes and fragments. For the author, "on the contrary, the conditions of the new economy feed experiences adrift in time, from place to place, from job to job", corroding the "character qualities linking humans to each other" (SENNETT, 2007, p. 27). The motto "there is no longterm" is the most tangible sign of the new forms of organizing time, especially working time in contemporary period (op. cit., p. 21).

On the other hand, to escape from the instability of temporary, short-term employment, many workers set themselves up as individual entrepreneurs, particularly in the tertiary sector, with micro, small and medium enterprises.Unlike the logic of large companies and institutions, many of these enterprises are only local in scope or are family businesses. This occurs in core countries like Britain and the United States - where most companies have less than three thousand employees and some offer artisanal services, such as small-scale construction companies (SENNETT, 2006, p. 47) - but also in peripheral countries like Brazil, where entrepreneurship is being adopted on a large scale by low-income classes, as will be briefly analyzed below.

\section{POPULAR ENTREPRENEURSHIP IN BAHIA: NO TIME FOR LEISURE}

Before embarking on an analysis of the relationship between work and leisure in the universe known as "social class C" in Brazil, and particularly in working-classneighborhoods of two cities in the state in Bahia, at this point, there will be a brief and general presentation of the fundamentals of the study "Popular entrepreneurship and social mobility in different urban and regional contexts" and the first results of the two case studies carried out so far: in the neighborhood of Tomba, in Feira de Santana and the neighborhood of Paripe, in Salvador, in Bahia.

This research is an analysis of a new phenomenon, that has manifest itself in the working-class neighborhoods of Brazilian cities, which have an increasing number of residents with higher incomes and in the process of relative "social ascension". These areas have become more complex and self-sufficient, with the multiplication of sub-centers (and their diversification). In the first year of surveys, the commercial establishments and services in Tomba and Paripe were catalogued and mapped; questionnaires were also carried out with consumers and business people to delineate their profile in the more significant nuclei of commerce and services. Following the characterization of the enterprises and the profiles of the consumers and entrepreneurs, qualitative interviews were conducted with those entrepreneurs selected from the group that answered the questionnaires during the first phase of the research, in order to ascertain their position and condition in the social structure, with an emphasis on their trajectories and their capital (social, cultural and economic, in accordance with BOURDIEU, 2007[1979]). 
These interviews permitted the inference that the interviewees' ascension in the social structure implies the indebtedness and impoverishment of the social capital available to them. The schooling / cultural capital remain almost unchanged; continuing with studies requires a huge effort on the part of those who are willing to do so. There are strong indications that this ascension takes place more from the insertion in consumption than from an increase in the years of schooling or participation in cultural events or manifestations. On the other hand, it is also apparent that insertion through consumption can interfere in the life of social relations in the poorer neighborhoods analyzed, with the impoverishment of the social capital of entrepreneurs (and consumers), in their upward trajectories in the social structure of the cities and the regions where they operate, with implications therefore, for the social structure of the neighborhoods as a whole.

In the national context, it is also known that working-class neighborhoods - usually heavily populated and covering a big territory - concentrate a large part of the small businesses in Brazilian cities. Although it has not conducted actual statistical research, the Brazilian Service of Support for Micro and Small Businesses (SEBRAE) carried out a survey of businesses by neighborhood to create a Business Guide, in which for Salvador, the entrepreneurial neighborhoods are classed as: Brotas, Cabula, Cajazeiras, Itapuã, Itapagipe, Liberdade, Pau Miúdo, Pau da Lima, Paripe and Pernambués (SEBRAE, 2013).

According to the Brazilian Franchising Association, the growth of small businesses in the decade 2000 - 2010 is related to the ascension of more individuals to class $C$, who use their own resources or bank loans to start new businesses (BORGES, 2013, p. 1-3). In addition, SEBRAE has developed mobile collective taskforces on "individual entrepreneurship" in low-income neighborhoods in cities in Bahia, such as Feira de Santana, where the taskforce reached the Feira 9 and Morada das Árvores neighborhoods (www.ba.agenciasebrae.com.br/).

In this context, briefly considered, let us take up the question posed by Harvey for that particular universe: why do most of us actually have less time to think and relax, in a society in which technology increasingly liberates more free time for leisure? In the first place, most of the interviewees expressed their desire to expand their businesses, diversifying their activities or opening branches in other neighborhoods or downtown, or even in other cities in their region. The objective is always to grow and expand the undertaking, which naturally rules out leisure and fun in the short and medium term in the daily lives of these agents.

The interviews give insights that permit the entrepreneurs' trajectories to be situated in time and space, allowing the inference that the interviewees' ascension in the social structure implies, as mentioned above, the impoverishment of the social capital available to them, a fact which is evidenced by their restricted leisure time and by the lack of time for friends or to frequent cultural facilities. Despite belonging to different generations/age groups and urban-regional contexts, in practice, the interviewees restrict their leisure to activities with their families and resting at home.

When time permits, their preference is to frequent shopping malls, church services and mass with their families; they rarely go to the beach or a social club at the weekend. A few declared some interest in cultural activities such as the cinema, theatre or concerts. The most extreme cases stated that leisure is resting at home to "recharge your batteries" after the long workdays they face in their daily lives, as demonstrated below by some extracts selected from the interviews:

Look, here in Paripe I don't, I start at midday and leave at six o'clock, I don't have time. In Stella Maris [the neighborhood where the interviewee lives], I go to the beach, I really like the sea. But, I confess that today, if you ask me "what do you do outside of work?", I go home, put my dog on my lap, switch on the television and travel in whatever is on the television, to empty my mind because it gets really overloaded (MárciaVirgínia Medrados Vasconcelos, owner of a shop selling baby clothes and products in the Paripe neighborhood, Salvador). 
Nowadays I don't have time, we don't have weekends, we don't have time off, we don't have public holidays, we can't arrange to meet up with the family, because usually we are tired and we have to rest, any time we can rest is a priority. Nowadays time to rest has become a priority because we don't have a normal routine for resting, you have to open up at 7:00 in the morning and you don't know when closing time will be, you work on holidays, and you work all day Saturday and Sunday until 13:00 or 14:00. I say that because I don't work on Sundays but my husband does, he leaves home at 4:30 in the morning to catch the trade and stays until 14:00 while it's busy, so I lose that leisure time, I don't have any leisure (Joseany Santos, the owner of a packaging shop in the Tomba neighborhood, Feira de Santana).

... just soccer and some events here at the square. In my free time I rest, here it goes from 7 in the morning until 7 at night, sometimes I close the workshop but I still stay here working (Orlando dos Santos Silva, owner of a bicycle repair shop in the Tomba neighborhood, Feira de Santana).

Usually I stay at home at the weekend, when we go out it's quite quick. Usually it's home, when we don't visit a relative it's just home. Paripe we don't really... (You don't go to the beach here?) No, usually when we go to the beach it's further away. (But you go to the beach?) Yes, we do. (What about other places, even out of Paripe?) Yes, as we have a little girl we go to the zoo, the cinema, the shopping mall, the food court... (Leandro Santana, owner of a baby layette shop in Paripe neighborhood, in Salvador)

In my free time, we try to go to a club here called Águas Claras to relax my mind. There aren't many leisure options in Feira de Santana. I don't know if it counts as leisure, but I like to go to church, to take part in church activities (Joelio dos Santos Guerra, owner of a clothes shop in Tomba neighborhood, in Feira de Santana.)

The initial results of our research are consistent with Jessé Souza, as the so-called class C in the working-class neighborhoods of our cities bring together 'elements of a 'post-Fordist' worker's class (...) super-exploited, with no tradition of class solidarity and believing themselves to be their own bosses, with elements of a small bourgeoisie (...), in the sense of undertaking small businesses (...)" (SOUZA, 2015, s/p). The sociologist classifies these workers as "Brazilian warriors", the title of one of his most recent books (SOUZA, 2010):

The life of these "warriors" is completely different. It is marked by the absence of the "privileges of birth' that characterize the middle and upper classes. As they lack both the cultural capital so highly valued by the 'real' middle classes and the economic capital of the upper classes, they compensate for this lack with extraordinary personal effort, a doubled workday and an acceptance of every type of superexploitation of labor. This is the typical way of life of the working classes, thus our hypothesis of work developed in the book, which denies and criticizes the concept of the 'new middle class' and attempts to build a concept of the 'new working class', a product of the new conditions of international division of labor and the new global dominance of financial capital. These factors mean that this new class has nothing that is 'specifically Brazilian', as countries like China, India and a large part of Southeast Asia also owe a good part of their current dynamism to the same phenomenon (SOUZA, 2012, s/p).

Therefore, it can be affirmed that in the two working-class neighborhoods analyzed in this study, both entrepreneurs and consumers bring together exactly the characteristics listed by Souza for the "new working class", a stratum "that dynamized the Brazilian economy in the last decade and stimulated the market for the consumption of consumer goods" (SOUZA, 2015, s/p). This is a "very heterogeneous class, with important regional differences and ranges from small business owners to super-exploited workers with no social rights" (op. cit.). As highlighted here, the super-exploitation that Souza discusses also involves the free time of the workers and consumers in our research, who work many hours a day and who, in terms of schooling, have not reached higher education; in fact, some may not have completed elementary education. 
On the other hand, Souza's observations allude to Sennett's reflection regarding the social capital available to the different social classes, a fact that is also relevant in the context of core countries:

Here class is everything. A person from a privileged background can give themselves the luxury of strategic confusion, which does not happen with the child of the masses. Casual opportunities may be offered to a child of privilege due to their family environment and educational networks; privilege reduces the need to draw up strategies. Wide and strong human networks allow those at the top of the scale to deal with the present; networks are a safety net that reduces the need for long-term strategic planning (...). The masses however, have a sparser network of contacts and informal support, thus remaining more dependent on institutions (SENNETT, 2006, p. 76).

\section{TELEWORK AND CREATIVE LEISURE: THE AMPLIFICATION OF FREE TIME}

In his book "Creative Idleness", De Masi takes issue with a particular fact, found, according to him, frequently in Brazil, but sometimes in Italy as well, where he has seen in hotels and business centers "young men, who to earn their daily bread, spend the whole day inside an elevator, pressing the buttons that match the floor where clients want to get out". In view of this, he asks himself the reason for "belittling the life and intelligence of a youth to this point, keeping him closed up (...) eight hours a day in an elevator, to carry out idiotic and useless work", would it not be better for society in general to "give him the same amount of money, asking him in return to continue studying”. (DE MASI, 2000, p. 265).

For De Masi, post-industrial society, unlike rural or industrial society, is characterized by "a progressive delegation of work to electronic devices and an increasingly imbalanced relationship between the time dedicated to work and free time" (op. cit., p. 101). According to this logic, employees currently do in ten hours what they could accomplish in half the time, but "even if the working day was reduced by half (...) they would not create any hiring requirements for new staff. For this, it would be necessary to reduce the working day to three hours", and this reduction "should soon be followed by a week made up of a maximum of three working days, and every month would have, at the most, three weeks work". Even so, he believes that overtime would not be resolved, as people would stay at work many hours more than the regular working day, as they "are no longer used to staying at home, having time for themselves. (...) it's only in the long term that they will begin to appreciate free time and learn to value it" (op. cit., p. 164).

In accordance with the tendencies pointed out by Harvey and Sennett, De Masi also believes the a large part of new jobs generated in the USA, Japan and some European countries are jobs with reduced shifts, "of poor quality and poorly paid, most of which are done by immigrants" (op. cit., p. 100). However, De Masi differentiates this type of employment from part-time jobs, which, in his opinion, may "be the only form of work distribution that will be accepted by companies" (op. cit.). In the early 2000s, this was already taking place in countries like Holland, England and the United States, where part-time jobs accounted for 36\%, 22\% and $20 \%$ of the workforce, respectively. Even assuming that some people are overloaded at work due to badly distributed time and tasks, the author believes that "for the majority, work has reduced, so that many people can limit themselves to working five or, at the most, six hours a day" (op. cit., p. 160).

Another argument used by De Masi, to maintain that we generally work double the time required, is the research done on telework, "work that is not carried out in offices but one's own residence" (op. cit., p. 163). This research "shows that tasks that require eight to ten hours to accomplish at the company, can be accomplished, comfortably, in half the time: four to five hours at the most" (op. cit.). It is based on these ideas that the author proposes the introduction of telework and the "extremely short week", not only to radically change the organization of work, but also of life, as "people would have to plan a three or four-day weekend, instead of only two days, to recover their relationships with their wives and children and participate in civil life" (op. cit., p. 166). According 
to De Masi, "for the first time, (...) since the times of Taylor, changing the organization of work could mean "changing the organization of a whole existence"" (op. cit., p. 167), despite the fact that to do this would require "a re-education for free time" (op. cit.). To summarize:

Now it is possible to produce more and more goods and services with less and less human work. This means that nowadays for a 20-year-old young person, work only represents a seventh of all the time they are going to live (...) once executive tasks have been delegated to machines, for most people only the performance of intellectual, flexible, creative and entrepreneurial activities will be left: flow into study and games. (...) in other words, in the past years it was work that colonized free time. In the years to come free time will colonize work (DE MASI, 2000, p. 298).

Still according to De Masi, the present society should take on re-education for free time, which is also an education for idleness and creativity. In this light, individuals should be taught "the pleasure of living together, of introspection, of play and beauty" (op. cit., p. 313), the habit "of domestic activities and the autonomous production of many things that until now we have bought readymade" (op. cit.), the careful choice of places to rest, to be entertained and to have fun" (op. cit.), educating young people not just for the meanderings of the world of work but also for the "meanderings of various possible leisure options" (op. cit.). Re-education for leisure, creativity, solidarity and living together would thus be a need of post-industrial society, in which "most people do not know how to entertain themselves or even how to rest. This was understood when there was time" (op. cit., p. 314).

In contrast to the "universe of precision that coincides with industrial society", a universe that is "a rigid, programmed, linear, mathematized universe, in which the affluent abundance of standardized products is the product of creative work by a restricted elite of engineers and the mechanical work of an endless mass of executors" (op. cit., p. 295), post-industrial society, one of creative idleness and telework, is a universe of approximation, "a reflective, mature, conscious, complex approximation, which proceeds from scientific consciousness and precision, covering them and overcoming them" (op. cit., p. 297). This new society of approximation would, for De Masi, have advantages not only for companies and government offices, but also for the workers, due to the "autonomy of times and methods, the coincidence between the home and the workplace, the reduction in costs and the tiredness caused by commuting", among others (op. cit., p. 206).

Although controversial and considered utopian by his critics, it is worth reflecting prospectively about De Masi's proposals and their consequences for life in cities and the production of work and leisure spaces in cities and metropolises. On the one hand, telework opens up the possibility to "carry out activities without leaving home, saving the time that was spent on daily displacements between home and the office" (DE MASI, 2000, p. 155); and, on the other hand, "the requirements of specialized studies, work and culture increasingly impose changes from one city, country or continent to another" (op. cit.). obviously this has impacts on the organization of urban and metropolitan space as on this scale micro-displacements are reduced, while "displacements of a greater distance and duration multiply" (op. cit.).

We agree with De Masi that, if taken as true, his assertions would inevitably lead to an overhaul not only of cities (and metropolises), but also of nations, churches and companies that should equip themselves "for a collective life in which leisure and a growing number of attributes predominate, which should be carried out not for who works but for who rests and has fun" (DE MASI, 2000, p. 305). Of course this would also affect holidays and journeys, infrastructure and touristic flows, as well as maritime leisure resorts and the strategies of the tourism real estate market.

The dichotomy between the armies of tourists and holiday makers who are guided by a "consumer culture" would also change, the "millions of people who consider everything that is not invasive, noisy, full of confusion and haste 'funereal'" and those, much less numerous, who conceive of their vacations and their free time as "a culture of rest, reading and privacy" and consider "a 
hell everything that is not silence, order, calm, beautiful and clean" (op. cit., p. 307). Perhaps the scales tilt to the second group, in the medium or long term, with the re-education for free time and creative idleness, or, in the worse of hypotheses, a short-term deepening of the fissures and the segmentation/standardization of leisure spaces in contemporary cities and metropolises. "Meanwhile, traffic jams on the highways, railways and airports" and overcrowded hotel chains would get even bigger, indicating obvious signs of accelerated degradation (op. cit., p. 308).

On the scale of Nation-States the changes guided by the phenomenon of workless development will also affect governments and employment generation policies in the medium and long term, although this has not been the case until now:

Persecuted and threatened by an omnivorous technology, that devours at the same speed both the tasks attributed to laborers and employees or executives, instead of reducing working hours and the numbers of posts, governments reduce the fees and taxes to be paid by employers, incentivize foreign investment in their own countries, exhume once again the gangrenous forms of protectionism and incentivize contractual flexibility (DE MASI, 2000, p. 100).

With the drastic reduction in working hours, there would also be advantageous changes in the spatial organization of employment for society as a whole, as work could "even be spread to isolated, depressed or peripheral zones" (op. cit., p. 208). There would also be "more work available for hitherto excluded groups, such as people with disabilities and the elderly" and it would be possible to "free up overpopulated areas and, above all, reduce traffic and pollution, as well as road and street maintenance" (op. cit.). Among the possible disadvantages would be infrastructure costs (with cables, for example), the need to control the tariffs for information and communication services and the "possible emergence of poorly protected areas of work, and information technology work not declared to the tax authorities, which is much harder to control than traditional forms" (op. cit.).

Finally, there is a final question in response to those who consider De Masi's proposals utopian or unrealistic. How would "value" be generated in this new society of creative idleness, guided by free time and no longer by work time? To this question, the author replies that:

I deny (...) that creativity and innovation can germinate in organizations that are still administered with times, methods and command systems conceived one hundred years ago, not to innovate or create but to execute. That is all. (...) And who is it that pays? Citizens who are always working more. (...) This does not mean that they are going to stay home with their feet up, but it means that they will not have to kill themselves working anymore (...) In this new model of society (...) the winners, apart from the individual are science, art - therefore with an ulterior production of wealth - and the quality of life. (...) Where boring, tiring and dangerous operations are performed by machines and the wealth they produce is distributed by a principle of solidarity, and not competitiveness (DE MASI, 2000, p. 309-310).

\section{FINAL CONSIDERATIONS}

Finally, it is worth noting the main thesis defended here, that it is not possible to uncouple the discussion on spaces for leisure and reproduction in cities and metropolises from discussions regarding spaces for work and production. There is here a dialectic that makes work and leisure inseparable in the processes of the production of space on all the scales subject to this type of approach. So it is clear that this would have consequences for Urban Geography research dealing with the theme of contemporary leisure spaces. 
It also needs to be highlighted that capital-work relationships have undergone changes in the mode of capitalist production and that it is necessary to untangle and reveal these spatial-temporal relations to have a better understanding of the production of leisure and work spaces in the modern world, reflecting on the relationship between production and the organization of space in our cities and metropolises, in the light of their future tendencies and perspectives.

It has been demonstrated that the discussion on leisure and work in cities and metropolises demands a theoretical-conceptual deepening of the concept of social class, only set out here, as the different classes and fractions of classes are living the contradictions in the mode of production in diverse ways. This implies a radical dialectical approach to the production of leisure and work spaces in cities and metropolises for different social classes, avoiding the current tendency to prioritize the analysis, which is very evident in current research of leisure in Geography, of spaces destined to specific social segments, without this being made explicit in the research and the results presented.

In this context, it is also necessary to fill the gaps and crevices of playfulness and play in our cities and metropolises, evidencing the action and the strategies of the different groups, classes and fractions involved in these non-hegemonic process of the production of space (SERPA, 2007). This also requires some geographical imagination (SERPA, 2008) to think prospectively about the production of leisure and work spaces in the cities and metropolises of the future, including taking in to consideration utopian perspectives to dream of other possible worlds.

\section{BIBLIOGRAPHIC REFERENCE}

ARENDT, Hannah. A condição humana. 10. ed. Rio de Janeiro: Forense Universitária, 2000.

BORGES, Clarissa. Expansão da classe C impulsiona o comércio em bairros populares. Jornal A Tarde. Salvador, 28/4/2013, p. 1-3.

BOURDIEU, Pierre. A Distinção - crítica social do julgamento. Porto Alegre: Zouk, 2007 [1979].

DE MASI, Domenico. O ócio criativo. 2. ed. Rio de Janeiro: Sextante, 2000.

HARVEY, David. SIMPURB: Conferência de Encerramento. In: OLIVEIRA, Floriano G.; FREIRE, Désirée G.; DE JESUS, Gilmar Mascarenhas; OLIVEIRA, Leandro, D. de (Org.). Geografia Urbana. Ciência e Ação Política. Rio de Janeiro: Consequência, 2014. p. 45-64.

SEBRAE. Serviço Brasileiro de Apoio às Micro e Pequenas Empresas; DIEESE. Departamento Intersindical de Estatística e Estudos Socioeconômicos. Anuário do trabalho na micro e pequena empresa. Brasília, DF: SEBRAE/DIEESE, 2013.

SENNETT, Richard. O declínio do homem público. As tiranias da intimidade. 6 a reimpressão. São Paulo: Companhia das Letras, 1998.

SENNETT, Richard. A cultura do novo capitalismo. Rio de Janeiro; São Paulo: Record, 2006.

SENNETT, Richard. A corrosão do caráter. Consequências pessoais do trabalho no novo capitalismo. 12. ed. Rio de Janeiro; São Paulo: Record, 2007.

SERPA, Angelo. A Cidade e o Urbano: Discutindo o Conceito de Centralidades Lúdicas. Espaço e Geografia (UnB), Brasília, v. 10, p. 265-278, 2007.

SERPA, Angelo. Como prever sem imaginar? O papel da imaginação na produção do conhecimento geográfico. In: Angelo Serpa. (Org.). Espaços Culturais: Vivências, imaginações e representações. Salvador: Editora da Universidade Federal da Bahia - EDUFBA, 2008. p. 59-67.

SOUZA, Jessé. Os batalhadores brasileiros: nova classe média ou nova classe trabalhadora? Belo horizonte: Editora da UFMG, 2010.

SOUZA, Jessé. Entrevista de Jessé Souza ao blog Prosa em 12.05.2012. Disponível em: http://oglobo. globo.com/blogs/prosa/posts/2012/05/12/entrevista-com-sociologo-jesse-souza-444686.asp. Acesso em: 17 Fev. 2015. 
SOUZA, Jessé. Ralés, batalhadores e uma nova classe média. Entrevista especial com Jessé Souza. Disponível em: http://amaivos.uol.com.br/amaivos09/noticia/noticia.asp?cod_canal=41\&cod_noticia=16935. Acesso em: 17 Fev. 2015.

Submitted december 2015

Accepted january 2016 